\title{
Assessment of lead toxicity in red tilapia Oreochromis sp. through hematological parameters
}

\begin{abstract}
Van-Thanh Vo, Thai-Minh-Long Le, Thi-Quynh-Anh Duong, Nhat-Anh-Thu Mai, Huyen Nguyen Thi Thuong* Department of Human and Animal Physiology, Ho Chi Minh City University of Education, Vietnam

Abstract

Fish is one of the reliable biomonitoring used to assess the levels of heavy metal pollution in the aquatic environment. Analyzing the biological parameters of fish provides a predictable transformation of the underwater ecosystem and the current state of nursery water. Blood directly or indirectly reacts to changes in the environment, objectively reflects the physiological state and allows predicting the direction of adaptive responses in the body. According to the blood indicators and proper generalization of the blood system, we can estimate the physiological and pathological processes inside the body. This study aimed to estimate the effects of lead on hematological parameters in red tilapia. Fish were investigated for the effects of the lead after one week. Fish blood is taken from the tail vein by suction injection. Hematological parameters were determined by standard methods. The number of WBC is counted indirectly through blood smears stained Giemsa. The result of the study shows when the concentration of lead for infection increase from $0 \mathrm{mgL}^{-1}$ (control) to $0.5 \mathrm{mgL}^{-1}, 1.0 \mathrm{mgL}^{-1}$ and $1.5 \mathrm{mgL}^{-1}$, there is a decrease in the hematocrit, hemoglobin, RBC and increases of the mean corpuscular volume, mean corpuscular hemoglobin and mean corpuscular hemoglobin concentration, WBC. RBC and WBC have observed the shape. Blood cells of red tilapia Oriochromis sp. living in a lead polluted environment can be affected and result in many different values of hematological parameters. This is an adaptive reaction of the body in response to harmful factors at the cellular level.
\end{abstract}

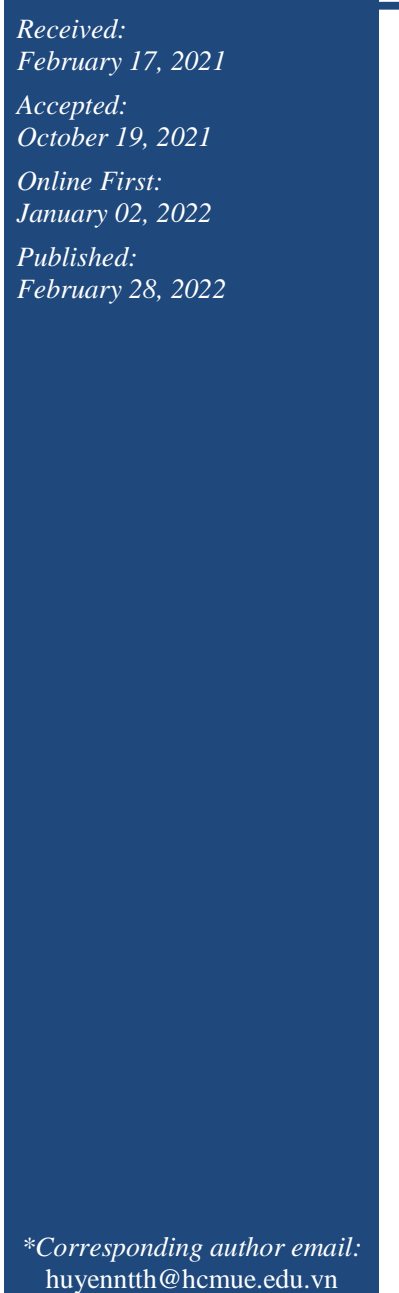

Keywords: Hematological parameters, Red tilapia, Heavy metal pollution, Oreochromis sp., Infection of lead

\section{How to cite this:}

Vo VT, Long Le TM, Duong TQA, Mai NAT and Thuong NHT, 2022. Assessment of lead toxicity in red tilapia Oreochromis sp. through hematological parameters. Asian J. Agric. Biol. 2022(2): 202101016. DOI: https://doi.org/10.35495/ajab.2021.01.016.

This is an Open Access article distributed under the terms of the Creative Commons Attribution 3.0 License. (https://creativecommons.org/licenses/by/3.0), which permits unrestricted use, distribution, and reproduction in any medium, provided the original work is properly cited.

\section{Introduction}

Environmental pollution from industrial complexes and livestock waste sources is a serious threat to various aquatic ecosystems. In particular, heavy metal pollution is being concerned by researchers. The studies about the heavy metal pollutant factors have shown that $\mathrm{Pb}, \mathrm{As}, \mathrm{Cu}, \mathrm{Pb}, \mathrm{Cr}$, $\mathrm{Ni}$ and $\mathrm{Hg}$ regularly exceeds the permissible standards in water and soil environments (Hou et al., 2013; Mansour and Sidky, 2002). Lead (Pb) is one of the most highly toxic metals (Mansour and Sidky, 2002). Lead toxicity causes serious damages to fish organs such as the liver, kidney and muscle (Al-Balawi et al., 
2013) and changes hematological parameters (Ergönül et al., 2012; Shah et al., 2020; Tulaby et al., 2020; Verma et al., 2020).

Fishes are considered the most sensitive aquatic animals to toxic ingredients present in water (Hemmadi, 2017). Fish is one of the reliable biomonitoring used to assess the levels of heavy metal pollution in the aquatic environment. Analyzing the biological parameters of fish provides a predictable transformation of the underwater ecosystem and the current state of nursery water (Authman et al., 2015; Lamas et al., 2007; Mohamed and Osman, 2014; Rashed, 2001). Blood directly or indirectly reacts to changes in the environment, objectively reflects the physiological state and allows predicting the direction of adaptive responses in the body (Nussey et al., 1995). Copper, cadmium, and mercury cause red blood cells (RBC) resolution of animals (Kotsanis et al., 2000), as well as impacting the environment that alters the morphology and size of RBC in many studies (Chernyavskikh et al., 2018; Yang and Chen, 2003). According to the blood indicators and proper generalization of the blood system, we can estimate the physiological and pathological processes inside the body (Nussey et al., 1995). Changes in blood physiological parameters (red blood cell count, white blood cell count, hematocrit, hemoglobin) are the most apparent manifestations of physiological reactions of blood with the influence of the environment. They are the helpful diagnosis of the health status of fish (Dethloff et al., 2001). Many studies have shown the effect of heavy metals on the hematological parameters of fish: decreasing in the amount of hematocrit (HCT), hemoglobin $(\mathrm{Hb}), \mathrm{RBC}$ and increasing in the number of white blood cells (WBC) (Kori-Siakpere and Ubogu, 2008; Nussey et al., 1995; Sharma and Langer, 2014).

Additionally, the study of Alkahem (1994) about the effect of nickel (Ni) on Oreochromis niloticus showed the opposite potential: increasing in the value of HCT, Hb, RBC and decreasing in the number of WBC (Alkahem, 1994). Although many studies of the effect of lead on hematological parameters in fish, there are no studies to mention the changes in hematological parameters and blood cell shapes of the red tilapia exposed to lead. Hence, this study aimed to estimate the effects of lead $(\mathrm{Pb})$ on hematological parameters and the change of blood cell shapes in red tilapia (Oreochromis sp).

\section{Material and Methods}

The experiment was conducted on red tilapia having an average weight of $158.25 \pm 9.31 \mathrm{~g} / \mathrm{fish}$ and an average length of $18.68 \pm 2.21 \mathrm{~cm}$. These fish were purchased at the National Center for Aquaculture Breeding Southern Vietnam of the Southern Research Institute for Aquaculture No. 2 in Tien Giang province (Vietnam). Fish were reared in the same conditions for 14 days. During the experiment, fish were fed three times/day, ensured a $36 \%$ crude protein, using Tilatech commercial feed of Cargil Vietnam Co., Ltd.

Red tilapia were reared in tanks with a size of $90 \mathrm{~cm} \times$ $70 \mathrm{~cm} \times 60 \mathrm{~cm}$. The fish were randomly divided into four groups with 15 individuals/group: one control and three experimental. Experimental groups infected with lead at concentrations of $0.5 \mathrm{mgL}^{-1}, 1.0 \mathrm{mgL}^{-1}$, $1.5 \mathrm{mgL}^{-1}$, control group was not lead infected $\left(0 \mathrm{mgL}^{-}\right.$

$\left.{ }^{1}\right)$. Fish were investigated for the effects of the lead after one week (seven days). Fish blood is taken from the tail vein by suction injection. The needles were impregnated with heparin at a concentration of $10 \mathrm{IU} / \mathrm{mL}$ to prevent blood clotting. Blood was contained in heparin-impregnated specialized blood storage tubes. Blood smears were prepared according to Hrubec et al. (Hrubec et al., 2000) and Giemsa stained.

HCT (\%) was determined by the centrifugation method. $\mathrm{Hb}(\mathrm{g} \%)$ was estimated by using Sahli's Hbometer (Dethloff et al., 2001). The number of RBC $\left(\times 10^{6} / \mathrm{mm}^{3}\right)$ was counted by the Neubauer chamber. Because RBC of fish have a nucleus preventing the count of WBC directly by the Neubauer chamber, so the number of WBC $\left(\times 10^{3} / \mathrm{mm}^{3}\right)$ was counted indirectly through blood smears stained Giemsa. Calculation of mean corpuscular volume (MCV), mean corpuscular hemoglobin $(\mathrm{MCH})$ and mean corpuscular hemoglobin concentration (MCHC) were carried out by using standard formulae:

$\operatorname{MCV}\left(\mu \mathrm{m}^{3}\right)=\operatorname{HCT}(\%) / \operatorname{RBC}\left(\times 10^{6} / \mathrm{mm}^{3}\right) \times 10$; $\mathrm{MCH}(\mathrm{pg})=\mathrm{Hb}(\mathrm{g} \%) / \mathrm{RBC}\left(\times 10^{6} / \mathrm{mm}^{3}\right) \times 10$; $\operatorname{MCHC}(\mathrm{g} / \mathrm{dL})=\mathrm{Hb}(\mathrm{g} \%) / \mathrm{HCT}(\%) \times 100$.

\section{Statistical analysis}

Statistical analyses were performed using Minitab 18 software and the data were presented as Mean \pm SD. The difference was considered to be statistically 
significant with $\mathrm{p} \leq 0.05$.

\section{Results and Discussion}

The following table presents the result of experiments about the changes in hematological parameters of red tilapia (HCT, Hb, RBC, WBC, MCV, MCH, MCHC) undergone the infection of lead with the concentrations: $0.5 \mathrm{mgL}^{-1}, 1.0 \mathrm{mgL}^{-1}$ and $1.5 \mathrm{mgL}^{-1}$ after seven days of infection.

Comparative analysis of the control group's data with that of the experimental groups clearly showed a marked decline in $\mathrm{RBC}, \mathrm{Hb}, \mathrm{HCT}$ and increasing WBC at the end of the experimental period in leadinfected fish, that is shown in table 1.

Table-1: Hematological parameters of Oreochromis sp. exposed to lead

\begin{tabular}{|c|c|c|c|c|}
\hline \multirow{2}{*}{$\begin{array}{l}\text { Hematologica } \\
\text { l parameters }\end{array}$} & \multirow{2}{*}{ Control } & \multicolumn{3}{|c|}{ Concentration of Lead $\left(\mathrm{mgL}^{-1}\right)$} \\
\hline & & 0.5 & 1.0 & 1.5 \\
\hline HCT $(\%)$ & $40.76 \pm 3.21^{\mathrm{a}}$ & $25.30 \pm 5.72^{\mathrm{b}}$ & $23.97 \pm 5.21^{\mathrm{bc}}$ & $21.80 \pm 3.18^{c}$ \\
\hline $\mathrm{Hb}(\mathrm{g} \%)$ & $7.96 \pm 0.69^{\mathrm{a}}$ & $5.92 \pm 0.47^{\mathrm{b}}$ & $5.57 \pm 0.58^{\mathrm{b}}$ & $5.04 \pm 0.52^{\mathrm{c}}$ \\
\hline $\begin{array}{c}\text { RBC } \\
\left(\times 10^{6} / \mathrm{mm}^{3}\right)\end{array}$ & $2.52 \pm 0.22^{\mathrm{a}}$ & $1.50 \pm 0.32^{\mathrm{b}}$ & $1.43 \pm 0.35^{\mathrm{b}}$ & $1.22 \pm 0.19^{\mathrm{c}}$ \\
\hline $\operatorname{MCV}\left(\mu \mathrm{m}^{3}\right)$ & $161.81_{\mathrm{c}} \pm 1.63$ & $168.67 \pm 2.75^{\mathrm{b}}$ & $167.15 \pm 3.52^{\mathrm{b}}$ & $178.98 \pm 2.18^{\mathrm{a}}$ \\
\hline MCH (pg) & $31.60 \pm 0.27^{\mathrm{d}}$ & $39.47 \pm 0.48^{\mathrm{b}}$ & $38.86 \pm 0.75^{\mathrm{c}}$ & $41.38 \pm 0.93^{\mathrm{a}}$ \\
\hline MCHC (g/dl) & $19.53 \pm 0.18^{\mathrm{c}}$ & $23.40 \pm 0.24^{\mathrm{a}}$ & $23.25 \pm 0.34^{\mathrm{b}}$ & $23.12 \pm 0.29^{b}$ \\
\hline $\begin{array}{c}\text { WBC } \\
\left(\times 10^{3} / \mathrm{mm}^{3}\right)\end{array}$ & $60.95 \pm 2.57^{\mathrm{d}}$ & $70.23 \pm 2.28^{\mathrm{c}}$ & $80.03 \pm 2.28^{b}$ & $86.05 \pm 2.22^{\mathrm{a}}$ \\
\hline
\end{tabular}

Notes: $\mathrm{a}, \mathrm{b}, \mathrm{c}, \mathrm{d}-$ The difference is statistically significant $(\mathrm{p}<0.05)$.

HCT is decreased from $40.76 \pm 3.21(\%)$ to $21.80 \pm 3.18(\%)$, statistically significant with $\mathrm{p}<0.001$. Specifically: at the concentration of $0.5 \mathrm{mgL}^{-1}$, it is lower $15.46 \% \quad(\mathrm{p}<0.001)$ than the control; at the concentration of $1.0 \mathrm{mgL}^{-1}$, it decreased $1.33 \%$ $(p>0.05)$ compared with group having the concentration at $0.5 \mathrm{mgL}^{-1}$; at $1.5 \mathrm{mgL}^{-1}$ concentration, HCT decreased $2.17 \%$ ( $>>0.05)$ compared with group of $1.0 \mathrm{mgL}^{-1}$ concentration; HCT at $1.5 \mathrm{mgL}^{-1}$ concentration decreased $3.5 \%(\mathrm{p}<0.001)$ compared with the group of $0.5 \mathrm{mgL}^{-1}$ concentration.

The $\mathrm{Hb}$ concentration collected after seven days in the blood of red tilapia decreased from $7.96 \pm 0.69 \mathrm{~g} \%$ in control to $5.04 \pm 0.52 \mathrm{~g} \%$ at a concentration of $1.5 \mathrm{mgL}^{-1}$. The $\mathrm{Hb}$ concentration of red tilapia at $0.5 \mathrm{mgL}^{-1}$ concentration decreased $2.04 \mathrm{~g} \%(\mathrm{p}<0.001)$ compared with the control; at concentration of $1.0 \mathrm{mgL}^{-1}$, it is decreased $0.35 \mathrm{~g} \%(\mathrm{p}>0.05)$ compared with the concentration of $0.5 \mathrm{mgL}^{-1}$, at concentration of $1.5 \mathrm{mgL}^{-1}, \quad \mathrm{Hb}$ decreased $0.53 \mathrm{~g} \% \quad(\mathrm{p}<0.05)$ compared with $1.0 \mathrm{mgL}^{-1}$ concentration. Red tilapia lives in a higher concentration of lead, $\mathrm{Hb}$ is more affected, the difference was statistically significant with $\mathrm{p}<0.001$.

The number of RBC decreases from $2.52 \pm 0.22 \times 10^{6} / \mathrm{mm}^{3}$ to $1.22 \pm 0.19 \times 10^{6} / \mathrm{mm}^{3}$ according to the concentrations of the infected lead after seven days. Specifically, the number of RBC of red tilapia in the $0.5 \mathrm{mgL}^{-1}$ concentration of lead decreased by $40.5 \%$; it is the concentration of $1.0 \mathrm{mgL}^{-1}$ decreased by $43.1 \%$; in the concentration of $1.5 \mathrm{mgL}^{-1}$ decreased by $51.6 \%$ compared with the control, all these differences were statistically significant with $\mathrm{p}<0.001$. The number of $\mathrm{RBC}$ at the $0.5 \mathrm{mgL}^{-1}$ concentration of lead and the $1.0 \mathrm{mgL}^{-1}$ concentration was not significantly different with $\mathrm{p}>0.05$.

$\mathrm{MCV}, \mathrm{MCH}, \mathrm{MCHC}$ depend on the change of HCT, $\mathrm{Hb}$ and RBC. Overall, MCV increased from $161.81 \pm 1.63 \mu \mathrm{m}^{3}$ to $178.98 \pm 2.18 \mu \mathrm{m}^{3}$ with $\mathrm{p}<0.01$. The decreasing numbers of RBC confirmed MCV increasing because of the inversion of $\mathrm{MCV}$ and $\mathrm{RBC}$. Increasing MCV is obviously due to enlarged RBC, possibly swelling of RBC (Sharma and Langer, 2014). Such change in MCH and MCHC may be due to increased lysis of $\mathrm{RBC}$ and reduction in cellular blood iron, which simply reflects a decline in $\mathrm{Hb}$ concentration due to metal toxicity (Sharma and Langer, 2014). That is the lack of peripheral blood in the body of poisoned fish.

Through the lead concentrations analyzed after seven days, the results indicate the decline of HCT, Hb and RBC compared to the control, consistent with similar trends reported about heavy metal effects with hematological parameters such as: copper $(\mathrm{Cu})$ and hematological consistent in Channa punctatus (Singh et al., 2008); hematological parameters changes of Oreochromis niloticus exposed to cadmium (Cd) (AlAttar, 2005) and continued with mercury ( $\mathrm{Hg}$ ) (Ishikawa et al., 2007). HCT is calculated as the ratio of the volume of RBC in a unit of blood. HCT, through decreased lead levels, shows the decreasing of the volume of RBC, which may be the reduction of the number of RBC and possibly the action of the circulatory system decreases when affected by lead (Kaya et al., 2013), by the reduction of $\mathrm{Hb}$ and $\mathrm{RBC}$ is anemia, not enough to response the amount of mature RBC in the peripheral blood system. Lead may have affected the blood transporters, dissolved blood, lysis pseudo-RBC, and released normal RBC 
in the blood circulation (Sharma and Langer, 2014). Blood cell-producing organs may have been affected by lead that reduces $\mathrm{RBC}$ production, leading to a sharp decline of RBC in the blood circulation when the fish live in an environment contaminated with lead. In 1985, Fänge \& Nilsson suggested that the spleen is an organ that stores blood, creates blood and destroys old blood cells and produces other mature cells (Fänge and Nilsson, 1985). The spleen is one of the organs sensitive to infectious agents from the surrounding environment. The lead acts on and disrupts the spleen's function, reducing the number of RBC circulating in the blood of red tilapia. This result is consistent with Zapata (1980), it was suggested that environmental impact conditions on the spleen caused microscopic blood loss and resulted in hemolysis (Zapata, 1980). Besides, lead causes anomalies in the shape of $\mathrm{RBC}$, there are many irregularly shaped RBC (Fig. 1).

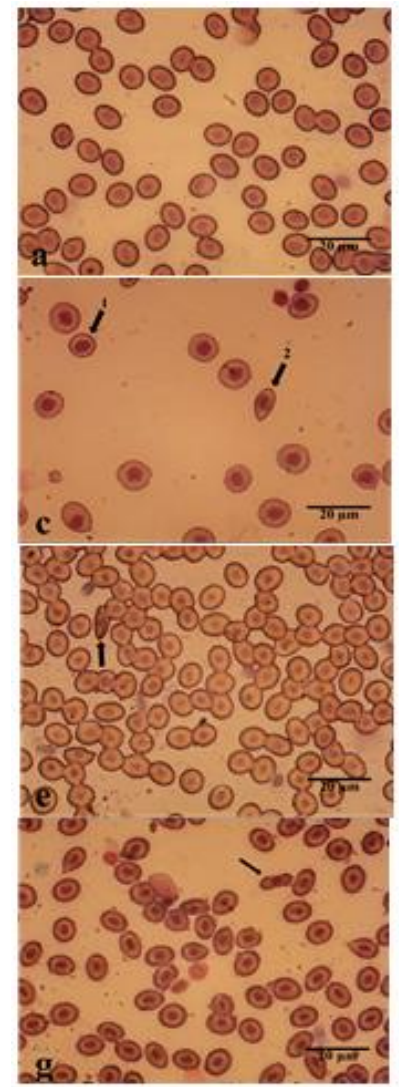

Figure-1: Red blood cells of red tilapia Oreochromis sp.: a - normal RBCs; b polynuclear RBC; c: c1- premature RBC, c2 water drop RBC; d - skewed RBC; e -crescent shaped $\mathrm{RBC}$; $\mathbf{f}$ - reticulocytes; $\mathrm{g}$-dumbbell $\mathrm{RBC}$; $h$ - micronuclei
According to Clauss et al. (2008), abnormal hematological morphology of fish related to RBC include polynuclear erythrocytes, deformed erythrocyte morphology, erythrocyte without nucleus, or RBC that remain alone nucleus without cytoplasm (Clauss et al., 2008). Reticulocytes appear, unknown causes, have not been mentioned, many studies have observed reticulocytes in their experiments (Hrubec et al., 2000). Brenden and Huizinga (1986) suggest that the presence of premature erythrocytes is often a symptom of anemia, the number of premature erythrocytes increases when the fishes are infected (Brenden and Huizinga, 1986). However, according to Clauss et al., the presence of premature erythrocytes in the blood circulation does not always indicate anemia but the presence of premature erythrocytes responses to the application of toxicants from the environment (Clauss et al., 2008).

Premature erythrocytes often have a more rounded shape and more swelling, which may cause the increase of MCV. Fish being infected by heavy metal for a long time can increase the occurrence of premature erythrocytes and malformed erythrocytes in the peripheral blood, which is a manifestation of the blood disease of fish (Vosyliene, 1999). The shape of the red cells is elliptical, the cell surface is convex. The shape and size of erythrocytes are determined by the cell membrane. Depending on the types of effects that lead to the changes in shape, which are suitable for environmental conditions, the impact at different environmental conditions changes the convex surface of RBC (Chernyavskikh et al., 2016). Ribarov and Benov (1981) suggest that peroxidation of membrane lipids is also a mechanism that can alter erythrocyte shape (Ribarov and Benov, 1981).

The study of Sharma and Langer (2014) also points out the effects of heavy metals that affect and alter the erythrocyte shape of fish (Sharma and Langer, 2014). The deformed erythrocyte morphology can lead to the loss of the primary function of RBC, such as oxygen transport to tissues, as well as deformed erythrocytes that clog blood vessels (Sharma and Langer, 2014; Yang and Chen, 2003). Therefore, premature erythrocytes and malformed erythrocytes do not guarantee the function of RBC in the blood system. In this study, the change in the shape and size of erythrocytes may be due to the destruction of mature erythrocytes and the appearance of more malformed and premature erythrocytes in peripheral 
blood. The red blood cell shape of red tilapia living in lead polluted environment becomes more rounded and bulging. Stress in the organism is stimulated by the effects of toxicants that have not compensated for sufficiently mature RBC, this lead to many different types of premature RBC in peripheral blood (Tomova et al., 2008). This is also the evidence of a shortened cycle of erythrocytes as well as detection of errors in hematopoiesis (Witeska and Kościuk, 2003).

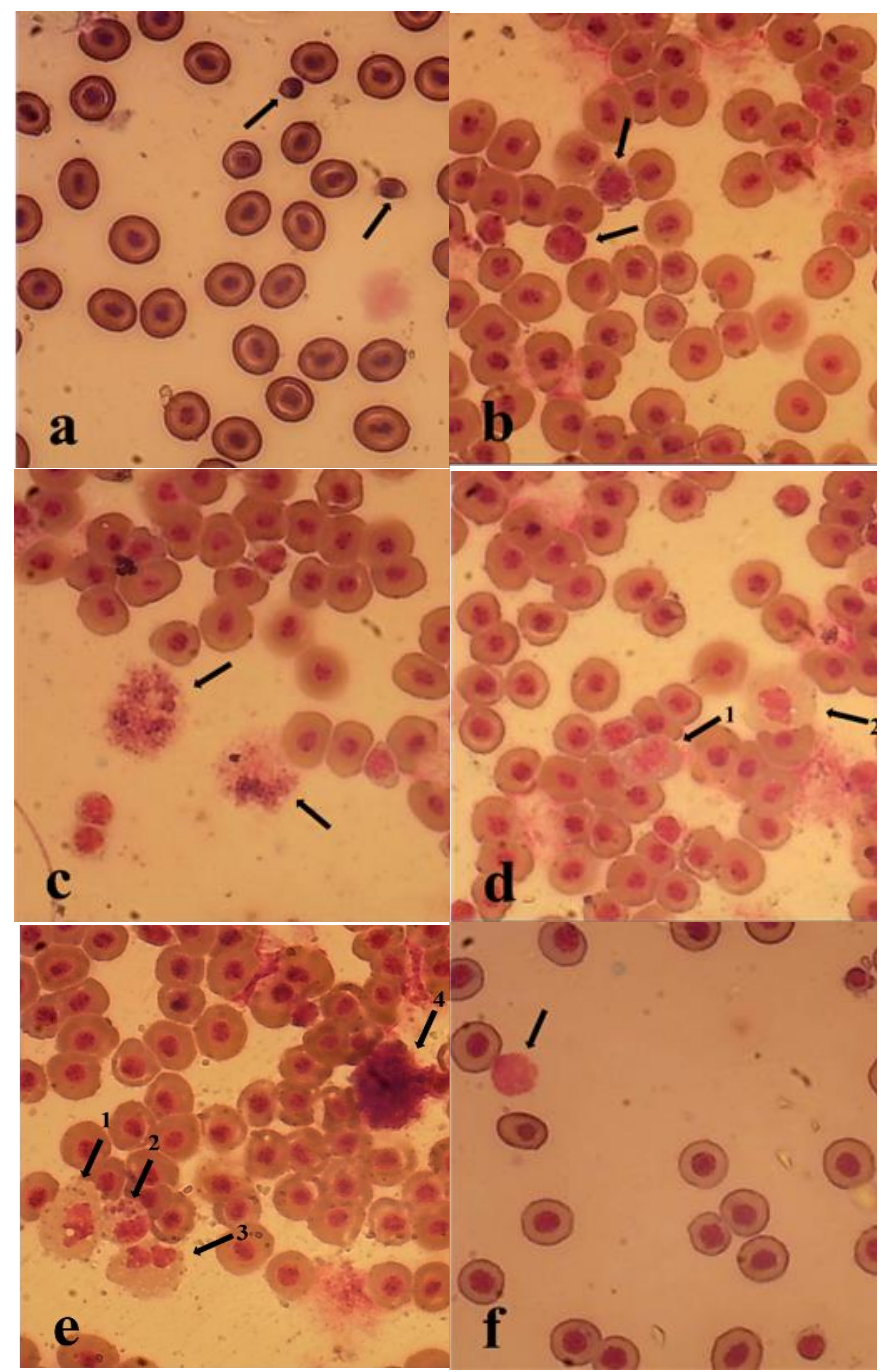

Figure 2. White blood cells of red tilapia (Oreochromis sp.): a - small lymphocyte; b, d-1 large lymphocyte; c - Eosinophilic leukocyte; f mono leukocyte; d-2, d-3, d-4, d-5, e-1, e-2, e-3 neutrophil; e-4 - basophilic leukocyte

The blood cells and $\mathrm{Hb}$ suffer from damages and dysfunction due to stress anemia caused by heavy metals (McKim et al., 1970). The decrease in $\mathrm{Hb}$ concentration is due to the heavy metal impacting directly on the enzyme system, which have functions to synthesize and regulate $\mathrm{Hb}$ concentration (Pamila et al., 1991). In addition, heavy metal effects reduce iron absorption leading to heme nucleus not forming and reducing $\mathrm{Hb}$ concentration (Joshi et al., 2002). This anemia is thought to occur because of $\delta$-amino levulinic acid dehydratase (ALA-D) inhibition by lead and thus causing severe damage in $\mathrm{Hb}$ synthesis. In heavy metals such as $\mathrm{Pb}, \mathrm{Zn}, \mathrm{Cd}, \mathrm{Hg}, \mathrm{Cu}$, only lead $(\mathrm{Pb})$ causes inhibition of ALA-D activity (Hodson et al., 1977).

After seven days, red tilapia lived in a lead polluted environment at concentrations of $0.5 \mathrm{mgL}^{-1}, 1.0 \mathrm{mgL}^{-1}$, $1.5 \mathrm{mgL}^{-1}$, the number of WBC increases from $60.95 \pm 2.57 \times 10^{3} / \mathrm{mm}^{3}$ (the control) to $86.05 \pm 2.22 \times 10^{3} / \mathrm{mm}^{3}$ (at $1.5 \mathrm{mgL}^{-1}$ concentration). The number of WBC of red tilapia in the concentration of $0.5 \mathrm{mgL}^{-1}$ increased by $9.28 \times 10^{3} / \mathrm{mm}^{3} \quad(\mathrm{p}<0.001)$ compared to the control; those of $1.0 \mathrm{mgL}^{-1}$ concentration increased by $9.8 \times 10^{3} / \mathrm{mm}^{3}(\mathrm{p}<0.001)$ compared with those of the $0.5 \mathrm{mgL}^{-1}$ concentration; Those of the concentration of $1.5 \mathrm{mgL}^{-1}$ increased by $6.02 \times 10^{3} / \mathrm{mm}^{3} \quad(p<0.001)$ compared to those of the concentration of $1.0 \mathrm{mgL}^{-1}$. The tendency to change the number of WBC is contrary to the changing trend of HCT, $\mathrm{Hb}$, and the number of RBC. Changes in WBC can be considered a measurement tool as well as an early warning signal of disorders in immunity and fish balance (BruckaJastrzębska and Protasowicki, 2005).

In this study, five types of WBC are detected: monocyte, lymphocyte, neutrophil, eosinophil, basophil (Fig. 2). Eosinophilic and basophilic leukocytes are two types of leukocytes rarely seen in previous studies. Most of the previous studies mainly found and observed three types: monocyte, lymphocyte, neutrophil (Bittencourt et al., 2003; Silveira-Coffigny et al., 2004). Several studies observed acidophil (Hrubec et al., 2000; Martins et al., 2008) but did not observe basophilic leukocytes. When the fish body is affected by harmful agents, the number of WBC increases significantly to counteract, the main function of WBC is generally destroying harmful agents invading the organism, creating immunity against pathogens (Martins et al., 2008; Sayed and Moneeb, 2015). The increase in the number of WBC undergone the effects of lead toxicity has shown an immune response in red tilapia. At lead concentrations of different infectious periods, the number of WBC increased in the reference range $\left(18.75-154.69 \times 10^{3} / \mathrm{mm}^{3}\right)$ (Hrubec et al., 2000; Mauel 
et al., 2007). This means the concentration of lead defined within the scope of the subject is still within the range of fish that can react to counteract toxicity.

\section{Conclusion}

In this study, blood cells of red tilapia Oriochromis sp. living in a lead polluted environment can be affected and result in many different values of hematological parameters. The changes in HCT, $\mathrm{Hb}$, $\mathrm{RBC}$ and the increasing potential of WBC and increased MCV are obviously observed. When the concentration of lead for infection increase from $0 \mathrm{mgL}^{-1}$ to $0.5 \mathrm{mgL}^{-1}, 1.0 \mathrm{mgL}^{-1}$ and $1.5 \mathrm{mgL}^{-1}$ after one week (7 days) of infection, there is mitigation of the number of red blood cells leading to a decrease in the HCT and hemoglobin level. The main reason for this phenomenon is lead toxicity directly causes damage to hematopoietic organs, reduces their function. The increase of the white blood cells is explained by the activation of the immune system under the effect of lead. This is an adaptive reaction of the body in response to harmful factors at the cellular level.

\section{Acknowledgement}

The authors are grateful to the Department of Human and Animal Physiology, Biology Faculty, Ho Chi Minh University of Education, Ho Chi Minh City, Vietnam for providing facilities for this study.

Disclaimer: None.

Conflict of Interest: None.

Source of Funding: None.

\section{References}

Al-Attar AM, 2005. Changes in haematological parameters of the fish, Oreochromis niloticus treated with sublethal concentration of cadmium. Pak. J. Biol. Sci. 8: 421-424. doi: 10.3923/pjbs.2005.421.424.

Al-Balawi HFA, Al-Akel AS, Al-Misned F, Suliman EAM, Al-Ghanim KA, Mahboob S and Ahmad Z, 2013. Effects of sub-lethal exposure of lead acetate on histopathology of gills, liver, kidney and muscle and its accumulation in these organs of Clarias gariepinus. Brazil. Arch. Biol. Technol. 56(2): 293-302. doi: 10.1590/S151689132013000200015.
Alkahem HF, 1994. The toxicity of nickel and the effects of sublethal levels on haematological parameters and behaviour of the fish, Oreochromis niloticus. J. Univ. Kuwait. 21: 243251.

Authman MM, Zaki MS, Khallaf EA and Abbas HH, 2015. Use of Fish as Bio-indicator of the Effects of Heavy Metals Pollution. J. Aquac. Res. Dev. 6: 328. doi: 10.4172/2155-9546.1000328.

Bittencourt NLR, Molinari LM, Scoaris DO, Pedroso RB, Nakamura CV, Ueda-Nakamura T, Filho BAA and Filho BPD, 2003. Haematological and biochemical values for Nile tilapia Oreochromis niloticus cultured in semi-intensive system. Acta Sci. Biol. Sci. 25: 385-389.

Brenden RA and Huizinga HW, 1986. Pathophysiology of experimental Aeromonas hydrophila infection in goldfish, Carassius auratus (L.). J. Fish Dis. 9: 163-167. doi: 10.1111/j.1365-2761.1986.tb00999.x.

Brucka-Jastrzębska E and Protasowicki M, 2005. Effects of cadmium and nickel exposure on haematological parameters of common carp, Cyprinus carpio L. Acta Ichthyol. Piscat. 35: 2938. doi: 10.3750/AIP2005.35.1.04.

Chernyavskikh SD, Quyet DH and Van Thanh V, 2018. Effect of Temperature on the Morphometrical and Physical Parameters of Erythrocytes and Polymorphonuclear Leucocytes in Carassius gibelio (Bloch). Inland Water Biol. 11: 92-96. doi: 10.1134/S1995082918010030.

Chernyavskikh SD, Vo VT, Erina TA, Yaroslavtsev SV, Vorobyeva OV and Krasovskaya LV, 2016. Morphofunctional indices of erythrocytes and polymorphonuclear leukocytes Rana ridibunda Pall under the influence of temperature factor. Int. J. Pharm. Technol. 8: 14486-14494.

Clauss TM, Dove ADM and Arnold JE, 2008. Hematologic Disorders of Fish. Veterinary Clin. North Am. Exot. Anim. Pract. 11: 445-462. doi: 10.1016/j.cvex.2008.03.007.

Dethloff GM, Bailey HC and Maier KJ, 2001. Effects of Dissolved Copper on Select Hematological, Biochemical, and Immunological Parameters of Wild Rainbow Trout (Oncorhynchus mykiss). Arch. Environ. Contam. Toxicol. 40: 371-380. doi: $10.1007 / \mathrm{s} 002440010185$.

Ergönül MB, Atasağun S and Kocatürk K, 2012. Alterations in the hematological and biochemical parameters and plasma ion concentrations of common carp, (Cyprinus carpio L., 1758) after 
short term exposure to sub-lethal concentrations of lead. Kafkas Univ Vet Fak Derg. 18(2): $297-$ 302. doi: 10.9775/kvfd.2011.5449.

Fänge $\mathrm{R}$ and Nilsson S, 1985. The fish spleen: structure and function. Experientia. 41: 152-158. doi: 10.1007/BF02002607.

Hemmadi V, 2017. A critical review on integrating multiple fish biomarkers as indicator of heavy metals contamination in aquatic ecosystem. Int. J. Bioassays. 6(9):5494-5506. Doi: 10.21746/ijbio.2017.9.5.

Hodson PV, Blunt BR, Spry DJ and Austen K, 1977. Evaluation of Erythrocyte $\delta$-amino Levulinic Acid Dehydratase Activity as a Short-Term Indicator in Fish of a Harmful Exposure to Lead. J. Fish. Board Can. 34: 501-508.

Hou D, He J, Lü C, Ren L, Fan Q, Wang J and Xie Z, 2013. Distribution characteristics and potential ecological risk assessment of heavy metals $(\mathrm{Cu}$, $\mathrm{Pb}, \mathrm{Zn}, \mathrm{Cd})$ in water and sediments from Lake Dalinouer, China. Ecotoxicol. Environ. Saf. 93: 135-144. doi: 10.1016/j.ecoenv.2013.03.012.

Hrubec TC, Cardinale JL and Smith SA, 2000. Hematology and Plasma Chemistry Reference Intervals for Cultured Tilapia (Oreochromis hybrid). Vet. Clin. Pathol. 29: 7-12. doi: 10.1111/j.1939-165X.2000.tb00389.x.

Ishikawa NM, Ranzani-Paiva MJT, Lombardi JV and Ferreira CM, 2007. Hematological parameters in Nile Tilapia, Oreochromis niloticus exposed to sub-letal concentrations of mercury. Braz. Arch. Biol. Technol. 50: 619-626. doi: 10.1590/S151689132007000400007.

Joshi PK, Bose M and Harish D, 2002. Haematological changes in the blood of Clarias batrachus exposed to mercuric chloride. J. Ecotoxicol. Environ. Monit. 12: 119-122.

Kaya H, Akbulut M, Çelik EŞ and Yilmaz S, 2013. Impacts of sublethal lead exposure on the hemato-immunological parameters in tilapia (Oreochromis mossambicus). Toxicol. Environ. Chem. 95: 1554-1564. doi: 10.1080/02772248.2014.895363.

Kori-Siakpere O and Ubogu EO, 2008. Sublethal haematological effects of zinc on the freshwater fish, Heteroclarias sp. (Osteichthyes: Clariidae). Afr. J. Biotechnol. 7: 2068-2073. doi: 10.5897/AJB07.706.

Kotsanis N, Iliopoulou-Georgudaki J and KapataZoumbos K, 2000. Changes in selected haematological parameters at early stages of the rainbow trout, Oncorhynchus mykiss, subjected to metal toxicants: arsenic, cadmium and mercury. J. Appl. Ichthyol. 16: 276-278. doi: 10.1046/j.1439-0426.2000.00163.x.

Lamas S, Fernández JA, Aboal JR and Carballeira A, 2007. Testing the use of juvenile Salmo trutta L. as biomonitors of heavy metal pollution in freshwater. Chemosphere. 67: 221-228. doi: 10.1016/j.chemosphere.2006.10.040.

Mansour SA and Sidky MM, 2002. Ecotoxicological Studies. 3. Heavy metals contaminating water and fish from Fayoum Governorate, Egypt. Food Chem. 78: 15-22. doi: 10.1016/S03088146(01)00197-2.

Martins ML, Mouriño JLP, Amaral GV, Vieira Fn, Dotta G, Jatobá AMB, Pedrotti FS, Jerônimo GT, Buglione-Neto CC and Pereira-Jr G, 2008. Haematological changes in Nile tilapia experimentally infected with Enterococcus sp. Braz. J. Biol. 68: 657-661. doi: 10.1590/S151969842008000300025.

Mauel MJ, Miller DL and Merrill AL, 2007. Hematologic and plasma biochemical values of healthy hybrid tilapia (Oreochromis aureus $\times$ Oreochromis nilotica) maintained in a recirculating system. J. Zoo Wildl. Med. 38: 420-424. doi: 10.1638/06-025.1.

McKim JM, Christensen GM and Hunt EP, 1970. Changes in the Blood of Brook Trout (Salvelinus fontinalis) After Short-Term and Long-Term Exposure to Copper. J. Fish. Board Can. 27: 1883-1889. doi: 10.1139/f70-210.

Mohamed EHA and Osman AR, 2014. Heavy Metals Concentration in Water, Muscles and Gills of Oreochromis niloticus Collected from the Sewage-Treated Water and the White Nile. Int. J. Aquac. 4: 36-42. doi: 10.5376/ija.2014.04.0006.

Nussey G, van Vuren JHJ and du Preez HH, 1995. Effect of copper on the differential white blood cell counts of the Mozambique tilapia (Oreochromis mossambicus). Comp. Biochem. Physiol. C Pharmacol. Toxicol. Endocrinol. 111: 381-388. doi: 10.1016/0742-8413(95)00064-X.

Pamila D, Subbaiyan PS and Ramaswamy M, 1991. Toxic effects of chromium and cobalt on Sarotherodon mossambicus (Peters). Indian J. Environ. Health. 33: 218-224.

Rashed MN, 2001. Monitoring of environmental heavy metals in fish from Nasser Lake. Environ. Int. 27: 27-33. doi: 10.1016/S01604120(01)00050-2. 
Ribarov SR and Benov LC, 1981. Relationship between the hemolytic action of heavy metals and lipid peroxidation. Biochim. Biophys. Acta BBA - Biomembr. 640: 721-726. doi: 10.1016/0005-2736(81)90102-4.

Sayed AEDH and Moneeb RH, 2015. Hematological and biochemical characters of monosex tilapia (Oreochromis niloticus, Linnaeus, 1758) cultivated using methyl testosterone. J. Basic Appl. Zool. 72: 36-42. doi: 10.1016/j.jobaz.2015.03.002.

Shah N, Khisroon M and Shah SSA, 2020. Assessment of copper, chromium, and lead toxicity in fish (Ctenopharyngodon idella Valenciennes, 1844) through hematological biomarkers. Environ. Sci. Pollut. Res. Int. 27(26): 33259-33269. doi: 10.1007/s11356-020-09598-z.

Sharma J and Langer S, 2014. Effect of Manganese on haematological parameters of fish, Garra gotyla gotyla. J. Entomol. Zool. Stud. 2: 77-81.

Silveira-Coffigny R, Prieto-Trujillo A and AscencioValle F, 2004. Effects of different stressors in haematological variables in cultured Oreochromis aureus S. Comp. Biochem. Physiol. Part C Toxicol. Pharmacol. 139: 245-250. doi: 10.1016/j.cca.2004.11.009.

Singh D, Nath K, Trivedi SP and Sharma YK, 2008. Impact of copper on haematological profile of freshwater fish, Channa punctatus. J. Environ. Biol. 29: 253-257.

Tomova E, Arnaudov A and Velcheva I, 2008. Effects of zinc on morphology of erythrocytes and spleen in Carassius gibelio. J. Environ. Biol. 29: 897-902.

Tulaby DZ, Aramoon A, Alishahi M, Halimi M and Rahnama R, 2020. The Effects of Lead Toxicity on the Hematological Parameters Common Carp (Cyprinus carpio) at Varying Salinity Levels.
Iran. J. Toxicol. 14(1): 1-8. doi: 10.32598/ijt.14.1.1.

Verma V, Gupta N and Gupta D, 2020. Haemotoxicity of lead $(\mathrm{Pb})$ on the blood parameters of fresh water teleost Heteropneustes

\section{Contribution of Authors}

Vo VT: Designed experiment, helped in data analysis, write up and editing of the manuscript.

Long Le TM \& Duong TQA: Performed experiments, collected \& analysed data and wrote first draft of the manuscript.

Mai NAT: Performed experiments.

Huyen Nguyen Thi Thuong: Helped in data analysis, write up and editing of the manuscript.

fossilis (Bloch). Int. J. Pharm. Sci. Res. 11(3): 1444-1451. doi: 10.13040/IJPSR.09758232.11(3).1444-51.

Vosyliene MZ, 1999. The Effect of Heavy Metals on Haematological Indices of Fish (Survey). Acta Zool. Litu. 9: 76-82. doi: 10.1080/13921657.1999.10512290.

Witeska $M$ and Kościuk B, 2003. The changes in common carp blood after short-term zinc exposure. Environ. Sci. Pollut. Res. 10: 284-286. doi: 10.1065/espr2003.07.161.

Yang JL and Chen HC, 2003. Effects of gallium on common carp (Cyprinus carpio): acute test, serum biochemistry, and erythrocyte morphology. Chemosphere. 53: 877-882. doi: 10.1016/S0045-6535(03)00657-X.

Zapata A, 1980. Splenic Erythropoiesis and Thrombopoiesis in Elasmobranchs: An Ultrastructural Study. Acta Zool. 61: 59-64. doi: 10.1111/j.1463-6395.1980.tb01291.x. 